\title{
Reversion of Incommensurate Modulation in Cubic Lazurite: Example of Reversible Forced Equilibrium?
}

\author{
Vladimir L. Tauson*, Anatoly N. Sapozhnikov, Ekaterina V. Kaneva, Sergei V. Lipko \\ A. P. Vinogradov Institute of Geochemistry, Siberian Branch of the Russian Academy of Sciences, Irkutsk, Russia \\ Email: ${ }^{*}$ vltauson@igc.irk.ru
}

Received 20 June 2014; revised 25 July 2014; accepted 17 August 2014

Copyright (C) 2014 by authors and Scientific Research Publishing Inc.

This work is licensed under the Creative Commons Attribution International License (CC BY). http://creativecommons.org/licenses/by/4.0/

c) (i) Open Access

\section{Abstract}

The sample of cubic lazurite, collected in the Baikal region, with incommensurately 3D modulated (ITM) structure has been studied by the method of high-temperature X-ray powder diffraction. At short time of annealing in high-temperature diffraction experiment the modulation recovery proceeds during cooling down the sample to room temperature. The identity of the period of both initial and recovered modulation demonstrates that the system has a structural memory. The acquired results are interpreted through comparison of thermal behavior of lazurite, sodalite and quartz structures. It is supposed that two kinetically different and thermally activated processes proceed under heating: 1) reversible framework expansion due to $\mathrm{Si}-\mathrm{O}-\mathrm{Al}$ angle increase, and 2) equalizing of periodic local distortions via the diffusion-controlled transfer of cage ions between adjacent subcells. The second process seems to be much slower than the first one, especially at lower temperatures. With increasing temperature, both processes are activated. However, the framework expands more rapidly than the cage clusters migrate, and the periodic distortions of the framework are aligned. Under lower temperatures, the framework shrinks and again accommodates to the configuration of cage cations (clusters), which may be changed at high temperature and sufficient time or may not at lower temperature, short time, unfavorable $\mathrm{SO}_{2}$ fugacity values. In the first case the modulation disappears entirely, while in the second case it arises again. The probable reason for ITM formation is the balance of counteracting energetic terms: the elastic strain energy of structure deformation and the energy of cluster ordering providing the state of forced equilibrium. The excess free energy due to structure distortion is compensated by the increment associated with the cluster ordering process. However, no significant variations in sulphur anion speciation for different degrees of modulation retention were observed by XPS S 2p. This may be due to the ordering of Na- and Ca-containing clusters rather than the clusters with different sulphur species. ITM reversion is considered as an example of reversible forced equilibrium with completely reproducible forcing factor.

\footnotetext{
"Corresponding author.
}

How to cite this paper: Tauson, V.L., Sapozhnikov, A.N., Kaneva, E.V. and Lipko, S.V. (2014) Reversion of Incommensurate Modulation in Cubic Lazurite: Example of Reversible Forced Equilibrium? Natural Resources, 5, 761-771. 


\section{Keywords}

\section{Lazurite, High-Temperature X-Ray Diffraction, Incommensurate Modulation, Reversion Mechanism, Forced Equilibrium, Sulphur Speciation}

\section{Introduction}

Lazurite is a sulfur-containing aluminosilicate mineral with formula $\mathrm{Na}_{6} \mathrm{Ca}_{2}\left[\mathrm{Al}_{6} \mathrm{Si}_{6} \mathrm{O}_{24}\right]\left(\mathrm{SO}_{4}, \mathrm{~S}, \mathrm{Cl}\right)_{2}$. It is a member of the group of sodalite minerals and characterizes by an $\mathrm{Al}$, Si-ordered tetrahedral framework of corner-linked $\mathrm{SiO}_{4}$ and $\mathrm{AlO}_{4}$ tetrahedra. The framework contains large cubo-octahedral (sodalite-type) cages, each bounded by six four-fold and eight six-fold rings of tetrahedra. The cages are packed according to the bodycenter law, so that every six-fold ring is shared by the two cages, so forming a set of channels running through the corners and center of the unit cell. As a result, the framework is permeated by intersecting channels with the diameters not larger than six-rings. The sodalite cages are occupied by inter-framework cations $\left(\mathrm{Ca}^{2+}\right.$ and $\left.\mathrm{Na}^{+}\right)$ and anions $\left(\mathrm{SO}_{4}{ }^{2-}, \mathrm{S}^{2-}\right.$ and $\left.\mathrm{Cl}^{-}\right)$. Under certain conditions, the crossing channels may serve as paths for migrating cage ions. The diffraction pattern of isotropic cubic lazurite usually includes two types of reflections: basic reflections and satellites (Figure 1).

The basic reflections refer to a sodalite subcell, that is the basic cubic cell with unit cell edge $a=9.07 \AA$. An indicative feature of the modulation of lazurite structure is the presence of satellites in diffraction patterns, the additional reflections close to certain basic reflections. The appearance of satellites is usually referred to periodic

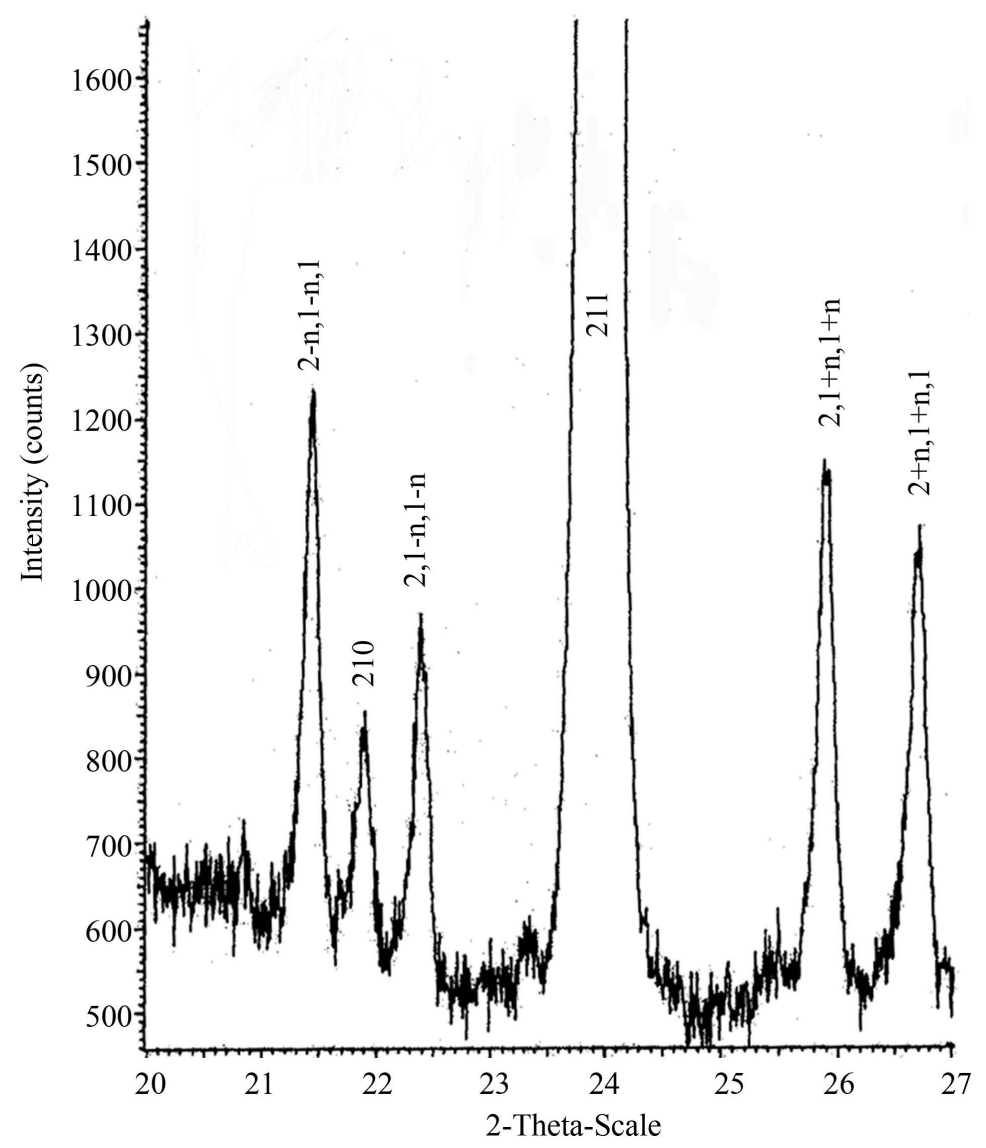

Figure 1. X-ray diffraction pattern of cubic ITM lazurite. The fragment contains basic (Bragg) reflections 210 and 211 (utmost intensive one) and satellite reflections. 
distortions of the main structure [1] [2]. In cubic lazurite the modulation is three-dimensional; the period of modulation $\left(T_{m}\right)$ is not commensurate with unit cell $a$ of basic structure and relates to it as $\sim 4.6$. Reciprocal relation $\left(n=a / T_{m}\right)$ denotes the parameter of structure modulation $n$, which determines the relative displacement of satellites from the basic reflections along the reciprocal lattice axis. The satellite position in the reciprocal space can be expressed as $h \pm n, k \pm n, l$, where $h, k, l$ donotes the Miller indices of reflections of basic cubic cell, $n$ is the modulation parameter of mineral structure. The interplanar spacing $(d)$ of satellites can be calculated [3] from the expression (1):

$$
\frac{1}{d_{(h \pm n),(k \pm n), 1}^{2}}=\frac{(h \pm n)^{2}+(k \pm n)^{2}+l^{2}}{a^{2}} .
$$

The origin and stability of incommensurable three-dimentional modulation (ITM) of cubic lazurite are poorly known, despite all the attempts recently undertaken to clarify the situation [4]-[9]. For instance, the possibility, conditions and reasons of the modulation reversion and retention are not fully understood.

\section{Experiments and Results}

\subsection{X-Ray Diffraction}

The samples with ITM structure were extracted from the lazurite-bearing metasomatites at the lazurite deposit Pokhabikha of the Slyudyanka metamorphic sequence (Southern Baikal region in East Siberia). The lazurite grains were carefully handpicked and cleaned off contaminants, mainly calcite, diopside and pyrite, under a binocular microscope. The samples were powdered to $\sim 0.02 \mathrm{~mm}$ and then heated stepwise at discrete steps of $50^{\circ} \mathrm{C}$ up to $750^{\circ} \mathrm{C}$ in a high-temperature heating cell HTC16 of the X-ray powder diffractometer D8 ADVANCE (Bruker). The samples were subsequently cooled down following the same regime. Previous data obtained for ITM-lazurite samples, heated at different temperature, time, sulfur dioxide fugacity and then quenched [4] [6]-[9] are also used in this study.

At each temperature step of both heating and cooling of a sample, the data acquisition was performed in two ranges of diffraction angles 29: from 20 to 27 and from 56 to 58 degrees. The rate of heating (cooling) was 10 degrees per minute with 1 min exposure at each temperature, before taking the XRD pattern. Experimental conditions were as follows: Cu-radiation, Göbel mirror, $40 \mathrm{kV}, 40 \mathrm{~mA}$, time per step $1 \mathrm{~s}$ and step size $0.01^{\circ}$.

An increase in temperature leads to a displacement of all peaks in the diffraction pattern of lazurite to the lower angles. The intensity of basic (Bragg) reflections remains roughly unchanged in contrast to a decrease in intensity of satellite reflections. At temperatures higher than $600^{\circ} \mathrm{C}$ no satellites were observed. Under the decreasing temperature the XRD peaks are shifted to the higher angles, and at temperatures lower than $600^{\circ} \mathrm{C}$ the satellite reflections appear again. Their intensities become higher with temperature decrease.

Thermal expansion of lazurite under heating leads to the enlargement of the unit cell parameter of basic cell from 9.069 to $9.167 \AA$. The parameter $a$ is gradually and nonlinearly enlarged up to $\sim 600^{\circ} \mathrm{C}$. At higher temperatures the rate of the parameter change becomes appreciably lower providing the appearance of inflection or discontinuity in the plot of temperature dependence (Figure 2(a)).

In $a-T$ plot, the points coincide for heating and cooling conditions over the range of $600^{\circ} \mathrm{C}-750^{\circ} \mathrm{C}$. At the temperatures lower than $600^{\circ} \mathrm{C}$, the cooling curve lies somewhat higher than the heating one. Figure 2 demonstrates the temperature dependences of unit cell edges for sodalite and quartz obtained under the same experimental conditions, for comparison. In the discussed temperature interval the unit cell parameter of sodalite sample, collected in the Slyudyanka locality in the Southern Baikal, also enlarges smoothly and nonlinearly but without inflection (Figure 2(b)); the quartz unit cell edge $(a)$ also increases to the temperature somewhat higher than $600^{\circ} \mathrm{C}$, then its growth stops (Figure 2(c)). A hysteresis is not observed in both cases. Note that $\alpha-\beta$ transition in quartz occurs at $573^{\circ} \mathrm{C}$.

The comparison of the curves of temperature dependences of unit cell edges of quartz, solalite and lazurite allowed the conclusions to be made on the structural and chemical changes in cubic ITM lazurite, when it is heated and cooled. Consider the quartz plot reflecting the reversible phase transition from trigonal to hexagonal modification. The framework of trigonal quartz expands under heating; the angle $144^{\circ}$ of $\mathrm{Si}-\mathrm{O}-\mathrm{Si}$ is enlarged to $\sim 180^{\circ}$ in hexagonal quartz; it becomes a topological barrier, which restricts the further growth of the unit cell edges under temperature increase. The lazurite and sodalite structures are based on flexible sodalite framework, which can shrink or unfold depending on temperature [10]. Thus, when comparing the temperature dependences 


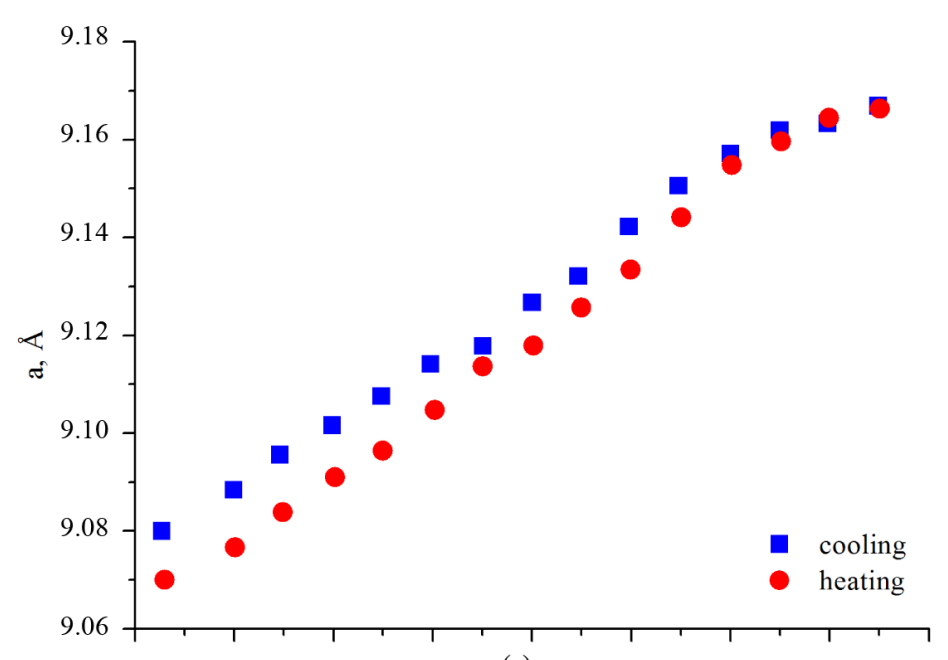

(a)

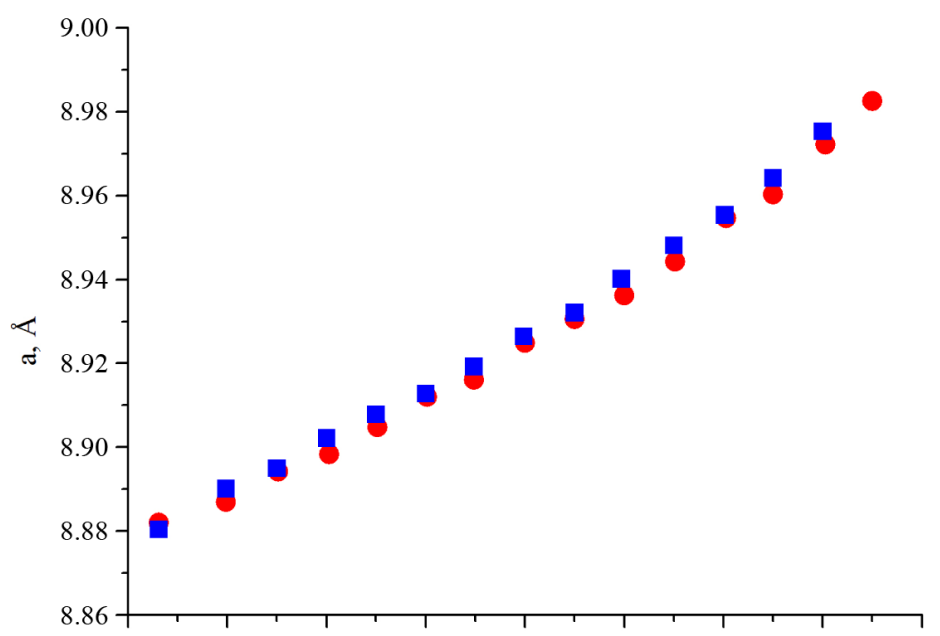

(b)

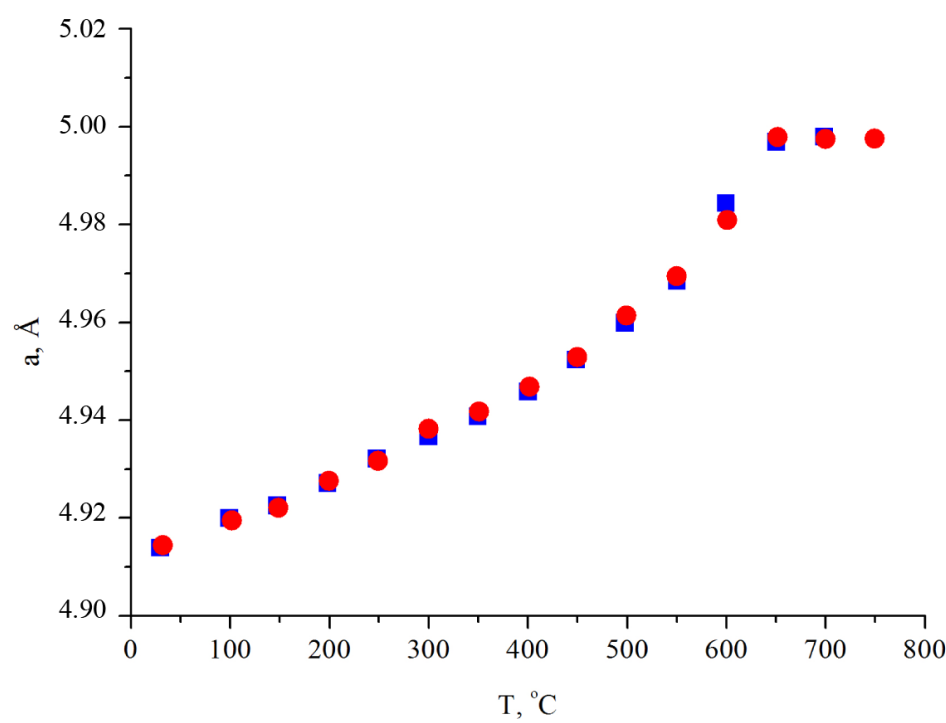

(c)

Figure 2. Behavior of unit cell parameter $a$ of lazurite (a), sodalite (b), and quartz (c) under heating and cooling of samples. Parameters are calculated from $d$-spacing of reflection 440 (lazurite and sodalite) and 220 (quartz). 
of unit cell edges of lazurite and sodalite we suppose that the topology of sodalite framework causes constraints for further unfolding of structure after the unit cell edge takes the value of $\sim 9.160 \AA$. In quartz structure the same restriction (i.e., the topological barrier) appears after the unit cell parameter $a$ attains the value of about $5.0 \AA$ (Figure 2(c)). A hysteresis observed in the lazurite curves may be explained by a partial oxidation of sulfide sulfur. This is supported by the fact, that repeated heating and cooling of one and the same sample exhibit no such hysteresis and fully reproduce the data on cooling obtained in the first attempt.

The change in modulation period or modulation wavelength $\left(T_{m}\right)$ with temperature can be determined by accounting for the displacement of satellite reflections $2+n, 2+n, 1$ and $2-n, 2-n, 1$ in XRD pattern.

The parameter of structure modulation is expressed as:

$$
n=\frac{a^{2}}{12}\left(\frac{1}{d_{2+n, 1+n, 1}^{2}}-\frac{1}{d_{2-n, 1-n, 1}^{2}}\right),
$$

where the basic unit cell parameter $a$ is calculated using reflection 440 . This value corresponds to the temperature, for which parameter $n$ is determined.

The interplanar spacings for satellite reflections and basic cell parameter are given in Table 1.

The analysis of available data shows that the values of a relative displacement of satellites from basic reflections are nearly the same under heating and cooling and equal to $n=0.2167(7)$. As far as $n=a / T_{m}$, it means that the unit cell edge and the modulation wavelength are changed consistently at heating and cooling of cubic lazurite.

The intensity ratio of satellite $2-n, 1-n, 1$ and basic reflection $211\left(I_{s} / I_{b}\right)$ was assumed to be a measure of modulation development. This ratio is shown in Figure 3 as a quadratic function of temperature with a high reliability of approximation: $R^{2}=0.98$ under heating and 0.99 under cooling.

The higher the temperature the lower the ratio mentioned above and therefore the progress of modulation release. In samples heated to over $600^{\circ} \mathrm{C}$ satellites are absent in XRD patterns, and this ratio is equal to zero. However, satellites appear again under sample cooling to $550^{\circ} \mathrm{C}$, and their intensities are growing with temperature decrease indicating the modulation recovery. A lack of complete coincidence of corresponding data points

Table 1. X-ray powder diffraction data of cubic ITM lazurite at different temperatures.

\begin{tabular}{|c|c|c|c|c|c|c|c|c|c|c|}
\hline \multirow{2}{*}{$\mathrm{T}\left({ }^{\circ} \mathrm{C}\right)$} & \multicolumn{5}{|c|}{ Heating } & \multicolumn{5}{|c|}{ Cooling } \\
\hline & $a(\AA)^{\mathrm{a}}$ & $d_{1}(\AA)^{\mathrm{b}}$ & $d_{2}(\AA)^{\mathrm{c}}$ & $n$ & $I_{s} / I_{b} \quad(\%)^{\mathrm{d}}$ & $a(\AA)^{\mathrm{a}}$ & $d_{1}(\AA)^{\mathrm{b}}$ & $d_{2}(\AA)^{\mathrm{c}}$ & $n$ & $I_{s} / I_{b} \quad(\%)^{\mathrm{d}}$ \\
\hline 30 & 9.069 & 3.338 & 4.144 & 0.2163 & 2.1 & 9.079 & 3.337 & 4.146 & 0.2162 & 2 \\
\hline 100 & 9.078 & 3.341 & 4.148 & 0.2163 & 1.9 & 9.088 & 3.341 & 4.149 & 0.2163 & 1.8 \\
\hline 150 & 9.084 & 3.342 & 4.150 & 0.2165 & 1.9 & 9.095 & 3.344 & 4.150 & 0.2163 & 1.7 \\
\hline 200 & 9.090 & 3.345 & 4.153 & 0.2165 & 1.8 & 9.101 & 3.347 & 4.154 & 0.2168 & 1.7 \\
\hline 250 & 9.097 & 3.349 & 4.155 & 0.2166 & 1.8 & 9.108 & 3.349 & 4.155 & 0.2167 & 1.6 \\
\hline 300 & 9.105 & 3.350 & 4.158 & 0.2169 & 1.5 & 9.114 & 3.352 & 4.159 & 0.2164 & 1.4 \\
\hline 350 & 9.113 & 3.352 & 4.162 & 0.2168 & 1.4 & 9.118 & 3.355 & 4.164 & 0.2171 & 1.2 \\
\hline 400 & 9.119 & 3.355 & 4.163 & 0.2168 & 1.2 & 9.126 & 3.358 & 4.167 & 0.2173 & 1 \\
\hline 450 & 9.127 & 3.360 & 4.167 & 0.2163 & 1.1 & 9.132 & 3.363 & 4.168 & 0.2174 & 0.6 \\
\hline 500 & 9.134 & 3.366 & 4.171 & 0.2165 & 0.9 & 9.142 & 3.371 & 4.174 & 0.2173 & 0.3 \\
\hline 550 & 9.145 & 3.382 & 4.173 & 0.2161 & 0.4 & 9.151 & 3.384 & - & - & 0 \\
\hline 600 & 9.156 & - & - & - & 0 & 9.157 & - & - & - & 0 \\
\hline 650 & 9.160 & - & - & - & 0 & 9.161 & - & - & - & 0 \\
\hline 700 & 9.164 & - & - & - & 0 & 9.163 & - & - & - & 0 \\
\hline 750 & 9.167 & - & - & - & 0 & 9.167 & - & - & - & 0 \\
\hline
\end{tabular}

${ }^{\mathrm{a}}$ Basic unit cell edge; ${ }^{\mathrm{b}}$ Interplanar spacing of satellite reflection $2+n, 1+n, 1$ ( $n$-parameter of modulation); ${ }^{\mathrm{c}}$ Interplanar spacing of satellite reflection $2-n, 1-n, 1 ;{ }^{\mathrm{d}}$ Intensity ratio of satellite $2-n, 1-n, 1$ and basic reflection 211 . 


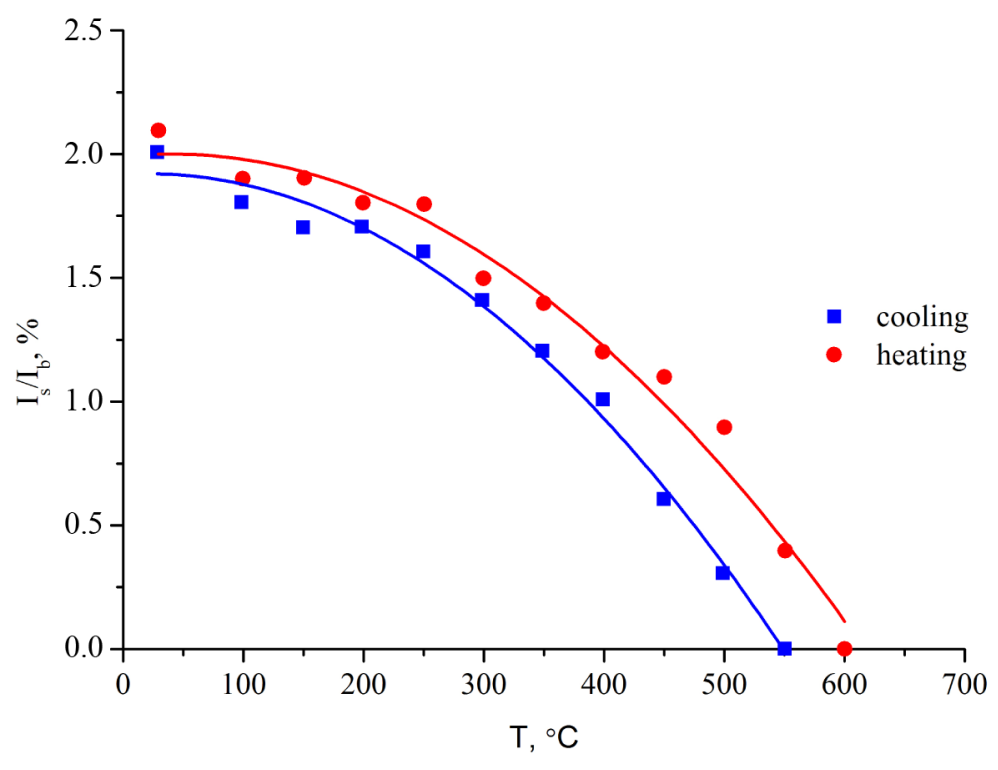

Figure 3. Development of modulation in cubic ITM lazurite as a function of temperature under heating and cooling of a sample.

in the heating and cooling curves is possibly due to a persistence of the processes of releasing and rebuilding modulation. As seen in Figure 3, after cooling to $30^{\circ} \mathrm{C}$ the ratio of satellite $2-n, 1-n, 1$ to basic 211 reflection intensity became almost the same, as it was in a starting sample. This is also valid for the other satellite reflections. As a result, the XRD pattern of a sample cooled down after heating up to $750^{\circ} \mathrm{C}$ is proved to be very similar to the pattern of initial sample in respect to positions and intensities of satellite reflections. Therefore, the satellite reflections, which disappear from XRD patterns of ITM lazurite under heating to over $600^{\circ} \mathrm{C}$, can appear again at cooling.

As previously reported [4], the satellites were not reproduced in XRD patterns of ITM lazurite heated at $\geq 600^{\circ} \mathrm{C}$ for 24 hours and then cooled to room temperature. When compared to the recently obtained experimental data, this suggests that a sufficiently long time of annealing at $\mathrm{T} \geq 600^{\circ} \mathrm{C}$ appears to be an important condition for eliminating periodic distortions of the base structure responsible for existence of satellites. Moreover, not only both temperature and time but also the fugacity of sulfur dioxide in gaseous phase should be considered as a critical parameter of the release and reversion of modulation. The progress of the modulation release at $600^{\circ} \mathrm{C}$ for 100 and 500 hours has a minimal value at $\mathrm{SO}_{2}$ fugacity $\sim 0.01$ bar [7]. However, at temperatures lower than $550^{\circ} \mathrm{C}$ the dioxide fugacity is not the critical parameter of ITM existence any more. As recently deduced from the X-ray photoelectron spectroscopic data [8], at $550^{\circ} \mathrm{C}$ only the processes inside of a particular cage take place, without interaction between S-containing species of different cages, as at higher temperatures.

\subsection{X-ray Photoelectron Spectroscopy}

The ITM lazurite crystals from the deposit Pokhabikha were carefully handpicked and separated from mineral contaminants, powdered to $\sim 0.02-0.03 \mathrm{~mm}$ grain size and annealed in air at $600^{\circ} \mathrm{C}, 650^{\circ} \mathrm{C}$ and $800^{\circ} \mathrm{C}\left( \pm 3^{\circ} \mathrm{C}\right)$ in the alundum crucible disposed inside of the quartz tube. After heating for the allowed time (Table 2), the tube was taken out from the furnace and cooled in ice water down to room temperature. The products were sealed in the Ar-filled ampoules for further XPS analysis. The ampoules were opened and the material quickly grinded just before its transfer to the analysis chamber.

X-ray photoelectron spectra were obtained using a Riber LAS-3000 spectrometer with non-monochromated $\operatorname{AlK}_{\alpha}(1486.6 \mathrm{eV})$ radiation, emitted by an electron beam accelerated at $10 \mathrm{kV}$ with a current of $20 \mathrm{~mA}$. Vacuum pressure in the analysis chamber was $6.7 \times 10^{-10}$ mbar. The spectrometer was equipped with an OPX-150 hemisphere detector. The binding energy scale of the spectrometer was calibrated with $\mathrm{Au}\left(4 \mathrm{f}_{7 / 2}\right)(\mathrm{BE} 84.0 \mathrm{eV})$ and $\mathrm{Cu}\left(2 \mathrm{p}_{3 / 2}\right)(\mathrm{BE} 932.67 \mathrm{eV})$. The $\mathrm{C} 1 \mathrm{~s}$ peak of hydrocarbon at $285 \mathrm{eV}$, which resulted from contaminations in every analysis chamber, was used to correct the binding energies for charging. The sulfur $2 p$ spin-orbit doublet peak was recorded and unfolded based on the $\mathrm{S} 2 \mathrm{p}_{3 / 2}$ and $\mathrm{S} 2 \mathrm{p}_{1 / 2}$ lines separated by $1.2 \mathrm{eV}$ using relative peak 
Table 2. XPS data of the annealing products of cubic ITM lazurite.

\begin{tabular}{|c|c|c|c|c|c|c|c|c|}
\hline Sample no. & $\begin{array}{l}\text { Annealing } \\
\text { conditions }\end{array}$ & $\begin{array}{l}\text { Photo-electron } \\
\text { peak }\end{array}$ & $\begin{array}{l}\text { Binding } \\
\text { energy } \\
(\mathrm{eV})\end{array}$ & $\begin{array}{c}\text { FWHM }^{\mathrm{a}} \\
(\mathrm{eV})\end{array}$ & $\mathrm{MPE}^{\mathrm{b}}$ & $\mathrm{MF}^{\mathrm{c}}$ & $\begin{array}{l}\text { Modulation } \\
\text { retention, \% }\end{array}$ & Ox/Red ${ }^{d}$ \\
\hline $\mathrm{PKH} / 0$ & $\begin{array}{l}\text { Initial } \\
\text { sample }\end{array}$ & $\begin{array}{l}2 p_{3 / 2} \\
2 p_{1 / 2} \\
2 p_{3 / 2} \\
2 p_{1 / 2} \\
2 p_{3 / 2} \\
2 p_{1 / 2} \\
2 p_{3 / 2} \\
2 p_{1 / 2}\end{array}$ & $\begin{array}{l}161.0 \\
162.2 \\
163.6 \\
164.8 \\
166.8 \\
168.0 \\
168.9 \\
170.1\end{array}$ & \begin{tabular}{l|}
3.0 \\
3.0 \\
3.0 \\
3.0 \\
3.0 \\
3.0 \\
3.0 \\
3.0
\end{tabular} & $\begin{array}{c}\mathrm{S}^{2-} \\
\mathrm{S}_{x}^{2-} \\
\mathrm{SO}_{3}^{2-} \\
\mathrm{SO}_{4}^{2-}\end{array}$ & $\begin{array}{l}0.05 \\
0.10 \\
0.44 \\
0.41\end{array}$ & - & 5.7 \\
\hline $\begin{array}{l}\text { PKH/ } \\
600 \_16\end{array}$ & $\begin{array}{c}600^{\circ} \mathrm{C} \\
16 \mathrm{~h}\end{array}$ & $\begin{array}{l}2 p_{3 / 2} \\
2 p_{1 / 2} \\
2 p_{3 / 2} \\
2 p_{1 / 2} \\
2 p_{3 / 2} \\
2 p_{1 / 2}\end{array}$ & $\begin{array}{l}162.8 \\
164.0 \\
166.9 \\
168.1 \\
168.9 \\
170.0\end{array}$ & $\begin{array}{l}1.9 \\
1.9 \\
2.8 \\
2.8 \\
1.7 \\
1.7\end{array}$ & $\begin{array}{c}\mathrm{S}_{x}^{2-} \\
\mathrm{SO}_{3}^{2-} \\
\mathrm{SO}_{4}^{2-}\end{array}$ & $\begin{array}{l}0.75 \\
0.19\end{array}$ & 93 & 13.4 \\
\hline $\begin{array}{l}\mathrm{PKH} / \\
600 \_30\end{array}$ & $\begin{array}{l}600^{\circ} \mathrm{C} \\
30 \mathrm{~h}\end{array}$ & $\begin{array}{l}2 p_{3 / 2} \\
2 p_{1 / 2} \\
2 p_{3 / 2} \\
2 p_{1 / 2} \\
2 p_{3 / 2} \\
2 p_{1 / 2}\end{array}$ & $\begin{array}{l}163.0 \\
164.2 \\
166.5 \\
167.7 \\
168.5 \\
169.7\end{array}$ & $\begin{array}{l}2.9 \\
2.9 \\
3.0 \\
3.0 \\
3.0 \\
3.0\end{array}$ & $\begin{array}{c}\mathrm{S}_{x}^{2-} \\
\mathrm{SO}_{3}^{2-} \\
\mathrm{SO}_{4}^{2-}\end{array}$ & $\begin{array}{l}0.17 \\
0.43 \\
0.40\end{array}$ & 73 & 4.9 \\
\hline $\begin{array}{l}\mathrm{PKH} / \\
650 \_1\end{array}$ & $\begin{array}{l}650^{\circ} \mathrm{C} \\
1 \mathrm{~h}\end{array}$ & $\begin{array}{l}2 p_{3 / 2} \\
2 p_{1 / 2} \\
2 p_{3 / 2} \\
2 p_{1 / 2} \\
2 p_{3 / 2} \\
2 p_{1 / 2} \\
2 p_{3 / 2} \\
2 p_{1 / 2}\end{array}$ & $\begin{array}{l}161.0 \\
162.2 \\
163.6 \\
164.8 \\
166.6 \\
167.8 \\
168.5 \\
169.7\end{array}$ & $\begin{array}{l}1.3 \\
1.3 \\
3.0 \\
3.0 \\
3.0 \\
3.0 \\
2.2 \\
2.2\end{array}$ & $\begin{array}{c}\mathrm{S}^{2-} \\
\mathrm{S}_{x}^{2-} \\
\mathrm{SO}_{3}^{2-} \\
\mathrm{SO}_{4}^{2-}\end{array}$ & $\begin{array}{l}0.05 \\
0.13 \\
0.51 \\
0.31\end{array}$ & 65 & 4.6 \\
\hline $\begin{array}{c}\mathrm{PKH} / \\
650 \_24\end{array}$ & $\begin{array}{l}650^{\circ} \mathrm{C} \\
24 \mathrm{~h}\end{array}$ & $\begin{array}{l}2 p_{3 / 2} \\
2 p_{1 / 2} \\
2 p_{3 / 2} \\
2 p_{1 / 2} \\
2 p_{3 / 2} \\
2 p_{1 / 2} \\
2 p_{3 / 2} \\
2 p_{1 / 2} \\
2 p_{3 / 2} \\
2 p_{1}\end{array}$ & $\begin{array}{l}161.5 \\
162.7 \\
163.6 \\
164.8 \\
166.8 \\
168.0 \\
169.2 \\
170.4 \\
163.6 \\
164 .\end{array}$ & $\begin{array}{l}1.1 \\
1.1 \\
2.9 \\
2.9 \\
3.0 \\
3.0 \\
2.8 \\
2.8 \\
3.0 \\
3.0\end{array}$ & $\begin{array}{c}\mathrm{S}^{2-} \\
\mathrm{S}_{x}^{2-} \\
\mathrm{SO}_{3}^{2-} \\
\mathrm{SO}_{4}^{2-} \\
\mathrm{S}_{x}^{2-}\end{array}$ & $\begin{array}{l}0.02 \\
0.11 \\
0.43 \\
0.44\end{array}$ & 15 & 6.7 \\
\hline $\begin{array}{l}\text { PKH/ } \\
800 \_0.3\end{array}$ & $\begin{array}{c}800^{\circ} \mathrm{C} \\
0.3 \mathrm{~h}\end{array}$ & $\begin{array}{l}2 \mathrm{p}_{1 / 2} \\
2 \mathrm{p}_{3 / 2} \\
2 \mathrm{p}_{1 / 2} \\
2 \mathrm{p}_{3 / 2} \\
2 \mathrm{p}_{1 / 2}\end{array}$ & $\begin{array}{l}167.1 \\
168.3 \\
169.0 \\
170.2\end{array}$ & $\begin{array}{l}2.8 \\
2.8 \\
2.0 \\
2.0\end{array}$ & $\begin{array}{l}\mathrm{SO}_{3}^{2-} \\
\mathrm{SO}_{4}^{2-}\end{array}$ & $\begin{array}{l}0.61 \\
0.27\end{array}$ & 0 & 8.0 \\
\hline
\end{tabular}

${ }^{\mathrm{a}}$ Full Width at Half Maximum of peak height; ${ }^{\mathrm{b}}$ Most Probable Entities of sulphur from BE values. $\mathrm{S}_{x}^{2-}=$ polysulphide $(x>2)$, $\mathrm{S}^{2-}=$ monosulphide anions; ${ }^{\mathrm{c}}$ Mole Fraction (total $\left.\mathrm{S}=1\right)$ calculated from areas of doublets; ${ }^{\mathrm{d} O x i d i z e d ~ t o ~ R e d u c e d ~ f o r m s ~ o f ~ s u l p h u r ~}\left(\mathrm{SO}_{4}+\mathrm{SO}_{3}\right) /\left(\mathrm{S}+\mathrm{S}_{x}\right)$.

intensities of 2:1 [11]. The lines were fitted using the program CasaXPS. A non-linear background subtraction and a Gaussian-Lorentzian model were used to obtain accurate BE and peak areas, and to resolve overlapping peaks. The Lorentz contribution of 0.3 to mixed function was taken as a most appropriate value. The sulphur anion speciation was interpreted following [12].

The results are shown in Table 2 and Figure 4.

We have recognized two oxidized (sulphate, $\mathrm{SO}_{4}^{2-}$ and sulphite, $\mathrm{SO}_{3}^{2-}$ ) and two reduced (monosulphide, $\mathrm{S}^{2-}$ and polysulphide, $\mathrm{S}_{x}^{2-}, x>2$ ) sulphur anionic species. The modulation retention was from 0 at $800^{\circ} \mathrm{C}$ to $93 \%$ at $600^{\circ} \mathrm{C}$. The most surprising result is the lack of significant change in sulphur anionic composition and its correlation with the modulation retention. The ratio of oxidized to reduced forms varies from 4.6 up to 13.3 irrespectively to ITM retention. Note a high percent of the modulation retention at $600^{\circ} \mathrm{C}$, in contrast to the previous data [4]. Although we studied the sample from the same deposit, there was a difference in the initial structure state (modulation development) and probably in composition $(\mathrm{Na} / \mathrm{Ca}$ ratio). The experimental condi- 

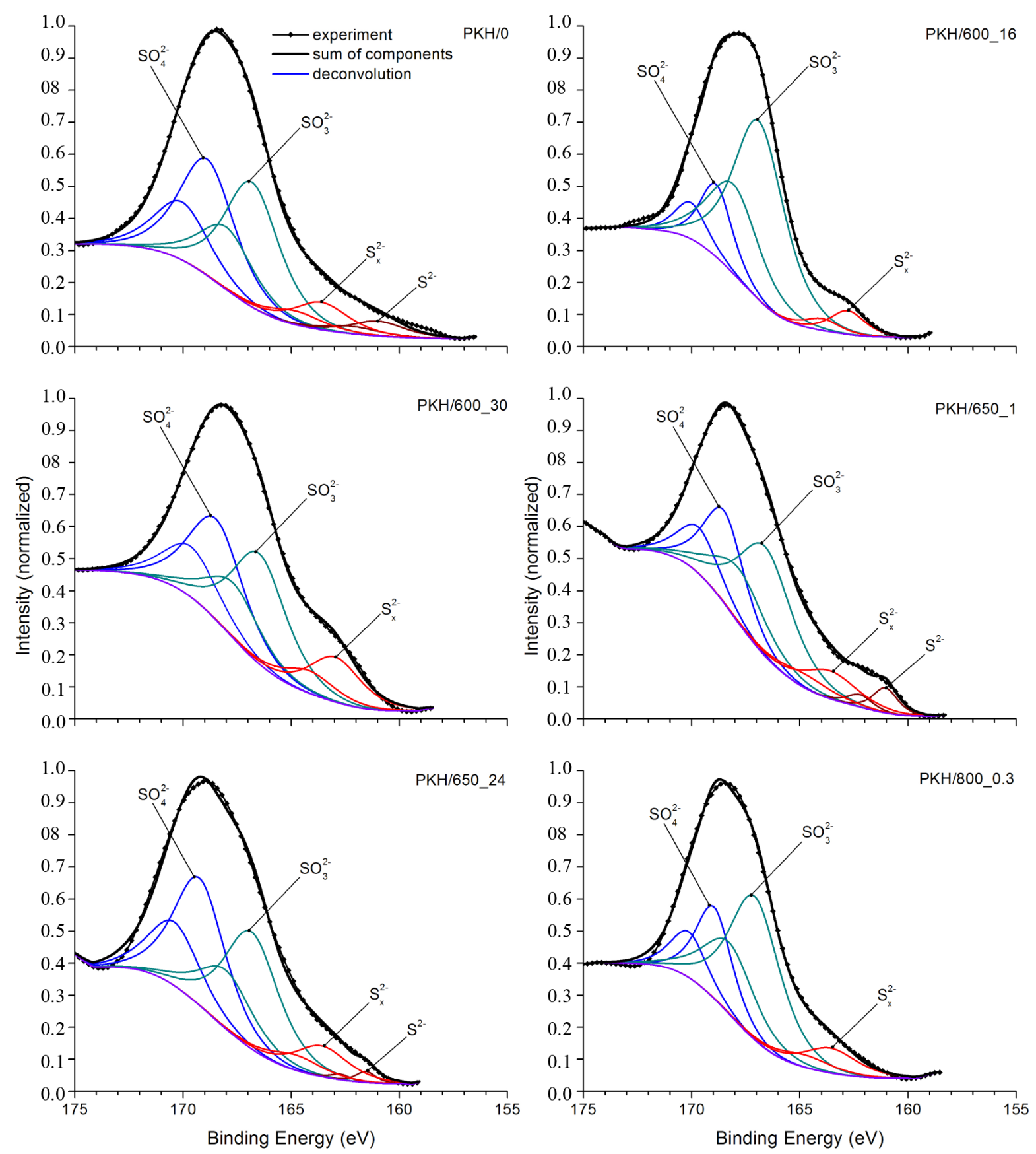

Figure 4. Sulphur $2 \mathrm{p}$ X-ray photoelectron spectra of cubic ITM lazurite: initial sample and the sample annealed in air at $600^{\circ} \mathrm{C}-800^{\circ} \mathrm{C}$ for different time.

tions were also not fully the same.

\section{Discussion}

\subsection{ITM in Terms of Forced Equilibrium Conception}

The formation of modulated structures in sodalite mineral family has recently been interpreted as a result of phase transitions [5] [10]. However, the incommensurable transitions in the insulators are often subjected to "competing, short-range interatomic forces of different ranges and similar magnitude" [13]. This situation has 
been specified as a forced equilibrium [14], and considered in respect to the lazurite modulated structures in [6]. It was reported that the most probable (although not solely possible) reason for ITM formation is the balance of counteracting energetic terms: the elastic strain energy of structure deformation and the energy of cluster ordering. In the other words, the excess free energy due to structure distortion is compensated by the increment associated with the cluster ordering process. Principally, three types of cluster cations can be implicated in cluster ordering process: Haüyne-type $\left(\left[\mathrm{Na}_{3} \mathrm{Ca} \cdot \mathrm{SO}_{4}\right]^{3+}\right)$, nosean-type $\left(\left[\mathrm{Na}_{4} \cdot \mathrm{SO}_{4}\right]^{2+}\right)$, sulphide sodalite-type $\left(\left[\mathrm{Na}_{4} \cdot \mathrm{S}\right]^{2+}\right.$ and $\left.\left[\mathrm{Na}_{3} \mathrm{Ca} \cdot \mathrm{S}\right]^{3+}\right)[12]$.

The most difficult problem for the forced equilibria conception is the proof of the state of forced equilibrium. As has been inferred [14], "it may be difficult to reproduce a forcing factor quantitatively although it is the only way for a direct experimental proof of the equilibrium". The ITM reversion is an interesting phenomenon from the forced equilibria standpoint because the system returns to the state that is thermodynamically unstable (in traditional understanding), not obeying the condition of mechanical equilibrium of continuous solid medium [6].

\subsection{Structural Mechanism and Energetic of ITM Reversion}

Turning back to the results of the present study, we can suppose two kinetically different thermally activated processes under lazurite annealing: (1) framework expansion due to Si-O-Al angle increase with temperature, and (2) equalizing of periodic local distortions via the diffusion-controlled transfer of cage ions between adjacent subcells. The first one is a reversible share process resulting in the change of orientation of the framework tetrahedra in the particular subcells of lazurite structure. The second process seems to be quite slower than the first one, especially at lower temperatures. In the course of it, the interframework ions pass from one subcell to another. At room temperature the substructure of cage ions is of prime importance in appearance of periodic distortions in the basic structure. A flexible framework is accommodated to this substructure of interframework ions (clusters) by geometrical distortions of basic structure, which seemingly contribute significantly to the intensities of satellite reflections [15] [16]. Under temperature elevation, both processes are activated but the framework expands more rapidly than cage clusters migrate. The periodic distortions of the framework are aligned and the satellite reflections disappear from the diffraction pattern. At decreasing temperature, the framework shrinks and again accommodates to the configuration of cage cations (clusters) which can, if high temperature and sufficient time is the case, or cannot be changed at lower temperature, short time, unfavorable $\mathrm{SO}_{2}$ fugacity. In the first case the modulation disappears entirely, in the second case it arises again. In our high-temperature $\mathrm{X}$-ray diffraction experiments the time of sample staying at $\mathrm{T} \geq 600^{\circ} \mathrm{C}$ was $\sim 2$ hours only. After 2 hours satellites appear again in XRD pattern under cooling, after $24 \mathrm{~h}$ at $650^{\circ} \mathrm{C}$ or $0.3 \mathrm{~h}$ at $800^{\circ} \mathrm{C}$ they do not (Table 2). Therefore, in the first case the configuration of interframework clusters was not changed, whereas in the second case the disorder of cage ions take place due to diffusion-controlled interaction between species of adjacent cages [7]-[9] resulting in irreversible modulation release.

In connection with the interpretation given above, a serious question arises. Contrary to classical thermodynamics, the recovery of modulation under cooling means that the system transforms to a state of higher free energy. It is essential to clarify the nature of forces preventing such system from transferring itself to a lower-energy state of a simple cubic sodalite-like structure by the usual nucleation-and-growth mechanism. Besides, it is critical to understand why the period of one and the same incommensurate modulation is reproduced displaying the effect of a structural memory.

From our viewpoint, the reason for the effects considered above is due to the fact that the system contains the stored energy of the substructure of ordered clusters. When the modulation releases, nothing can compensate this energy. However, if the clusters cannot be rearranged or there is no sufficient time to rearrange them owing to a slow diffusion, this stored energy may exert an induced deformation of the framework, tending to realize the energetic balance in the structure-a state of forced equilibrium [14]. At temperatures lower than $550^{\circ} \mathrm{C}$, under conditions of completely constraint intercell mobility of S-containing species, no other ways exist for the realization of the stored energy. Because of the lack of cluster redistribution, no disturbances of initial ratio of oxidized and reduced sulfur species occur, which provides the realization of the same type of modulation, in accordance with calculations in the forced equilibrium approach [6].

We have no information from the literature about an in situ high-temperature XRD study of ITM lazurite. Comparing to the studies on thermal expansion of synthetic sodalite with large additional anions I and $\mathrm{Br}$ [17] [18], it is remarkable that the discontinuity in temperature dependence of unit cell edge has been explained by displacement of $\mathrm{Na}$ cations along the body-diagonal direction of unit cell to the centers of six-fold rings. When 
shifting, the sodium cations can move apart the oxygen atoms of framework, meaning the reason of expansion. After the cations reach the centers of rings, the displacement does not proceed further with temperature and the framework does not further expand. Thus, in this model the driving mechanism of framework expansion under heating is the elongation of bonds between anions and cations in the unit cell; the framework passively expands under influence of cation displacement. The data of the present study provide evidence that the driving mechanism of sodalite framework expansion is connected with a fundamental property of flexible networks to increase the bond angle $\mathrm{Si}-\mathrm{O}-\mathrm{Al}$ (or Si-O-Si in quartz) up to a certain value under temperature elevation. This is supported by the fact of nonlinear growth of the unit cell parameter of quartz (Figure 2(c)) containing no interframework ions. Moreover, under the conditions of our experiments the unit cell edges of sodalite and lazurite increase almost equally (by 0.0940 and $0.0974 \AA$, respectively). The unit cell parameter of quartz increases only a little lesser (by $0.0841 \AA$ ), evidently indicating the uniform mechanism of thermal expansion of flexible frameworks of sodalite and quartz of different topology and chemical composition. The data obtained in the present study on the disappearance and recovery of satellite reflections in lazurite crystals indicate vigorously different rates of the share and diffusion processes and provide additional support to the mechanism considered above.

\subsection{Nature of Ordering Clusters.}

The question remaining is the type of clusters responsible for the forced equilibrium and the energy storage in the structure with released modulation. The lack of significant changes in sulphur speciation at different modulation retention (Table 2, Figure 4) allows us to suggest that these may be the Na- and Ca-containing clusters rather than the clusters containing different sulphur anions and the same $\mathrm{Na} / \mathrm{Ca}$ ratio. It seems not easy to resolve these clusters in S 2p XPS spectra because of the overlapping of peaks. However, Na- and Ca-clusters with $\mathrm{SO}_{4}^{2-}$ anions are resolved under specific annealing conditions of cubic ITM lazurite as well as in its triclinic variety [7] [12].

\section{Concluding Remarks}

The minerals of the sodalite group have been determined as "clathrasils", which are the compounds able to hold or encapsulate in the cages of their frameworks various cations and anions. Their diffusivity is restricted at low (room) temperature by the sizes of the six-fold rings [19]. However, under heating of a mineral the framework expands and the effective diameters of the rings increase. This gives rise to the processes of migration of interframework chemical species gaining additional kinetic energy due to thermal activation. In the case of lazurite crystals the activity of migration of cage ions is deciphered by the development of structural modulation. The migration ability enhances appreciably at $\sim 600^{\circ} \mathrm{C}-650^{\circ} \mathrm{C}$ after the parameter of the basic unit cell reaches 9.156 - $9.16 \AA$. At these temperatures the modulation disappears irreversibly, while at $550^{\circ} \mathrm{C}$ the modulation release progress is no more than $24 \%$ in the interval $100-2000 \mathrm{~h}$ under varying fugacity of $\mathrm{SO}_{2}$ [8]. At lower temperatures the contraction of the framework results in the isolation of sodalite-type cages, the migration of chemical entities comes to a stop and the mineral becomes "clathrasil" again. The reversion of modulation depends on how long the mineral is exposed to temperatures $550^{\circ} \mathrm{C}-600^{\circ} \mathrm{C}$ or even higher. If the cage clusters cannot (isolated cages!) or have no sufficient time to rearrange, i.e., short exposure time (minutes and hours), the modulation regenerates providing the structural memory of the system. At long exposure time (days and months) the cage clusters come to the disordered state and the modulation irreversibly disappears.

In any case, ITM lazurite was never heated in nature to more than $550^{\circ} \mathrm{C}$ through the geologically meaningful time.

The clusters responsible for ITM reversion are probably sulphate- and sulphite-containing cations with different $\mathrm{Ca}$ and $\mathrm{Na}$ ratio. ITM reversion is a unique example of reversible forced equilibrium. The system comes back to thermodynamically unstable state (in traditional sense) due to realization of stored energy of the structure of ordered clusters. The regeneration of forced equilibrium state is connected with the action of a completely reproducible forcing factor providing a compromise state with internal parameter (modulation wavelength) to be fixed [6] [14].

\section{Acknowledgements}

We are indebted to the Russian Foundation for Basic Research for supporting this project through grants 
08-05-98052-r_Siberia, 09-05-00089 and 12-05-00144.

\section{References}

[1] Cowley, J.M. (1979) What Are Modulated Structures? In: Cowley, J.M., et al., Eds., Modulated Structures, No. 9, American Institute of Physics, New York, 3-9.

[2] Organova, N.I. (1989) Crystal Chemistry of Incommensurate and Modulated Mix-layered Minerals. Nauka, Moscow. (In Russian)

[3] Sapozhnikov, A.N. (1990) Indexing of Extra Reflections in Powder Patterns of Lazurite in Connection with Structure Modulation Study. Zapiski Vserossiiskogo Mineralogicheskogo Obchshestva, 1, 110-116. (In Russian)

[4] Sapozhnikov, A.N., Ivanov, V.G., Medvedev, A.Ya. and Matveeva, L.N. (1991) Influence of Thermal Treatment on Parameters of Modulated Structure of Cubic Lazurite from Baikal. Izvestia Academii Nauk SSSR Neorganicheskie Materiali, 27, 811-815. (In Russian)

[5] Hassan, I. (2000) Transmission Electron Microscopy and Differential Thermal Studies of Lazurite Polymorphs. The American Mineralogist, 85, 1383-1389.

[6] Tauson, V.L., Akimov, V.V., Sapozhnikov, A.N. and Kuznetzov, K.E. (1998) Investigation of the Stability Conditions and Structural-Chemical Transformations of Baikal Lazurite. Geochemistry International, 36, 717-733.

[7] Tauson, V.L. and Sapozhnikov, A.N. (2005) Stability of the Modulated Structure of Baikal Lazurite and its Recrystallization at a Temperature of $600^{\circ} \mathrm{C}$ over a Wide Range of Sulfur Dioxide Fugacities. Crystallography Reports, 50, S1S9. http://dx.doi.org/10.1134/1.2133964

[8] Tauson, V.L., Sapozhnikov, A.N., Shinkareva, S.N. and Lustenberg, E.E. (2009) The Nature of the Stability of an Incommensurate 3D Structural Modulation in Baikal lazurite: Experimental Data at $550^{\circ} \mathrm{C}$. Geochemistry International, 47, 815-830. http://dx.doi.org/10.1134/S0016702909080059

[9] Tauson, V.L., Sapozhnikov, A.N., Akimov, V.V., Lipko, S.V., Shinkareva, S.N. and Lustenberg, E.E. (2010) Modulated Cubic Lazurite from the Baikal Region: Structure Transformed to the State of Forced Equilibrium. Doklady Earth Sciences, 433, 931-936. http://dx.doi.org/10.1134/S1028334X10070196

[10] Depmeier, W. (2005) The Sodalite Family_A Simple but Versatile Framework Structure. Reviews in Mineralogy \& Geochemistry, 57, 203-240. http://dx.doi.org/10.2138/rmg.2005.57.7

[11] Moulder, J.F., Stickle, W.F., Sobol, P.E. and Bomben, K.D. (1992) Handbook of X-Ray Photoelectron Spectroscopy. Perkin-Elmer Corporation, Eden Prairie.

[12] Tauson, V.L., Goettlicher, J., Sapozhnikov, A.N., Mangold, S. and Lustenberg, E.E. (2012) Sulphur Speciation in Lazurite-Type Minerals $(\mathrm{Na}, \mathrm{Ca})_{8}\left[\mathrm{Al}_{6} \mathrm{Si}_{6} \mathrm{O}_{24}\right]\left(\mathrm{SO}_{4}, \mathrm{~S}\right)_{2}$ and Their Annealing Products: A Comparative XPS and XAS Study. European Journal of Mineralogy, 24, 133-152. http://dx.doi.org/10.1127/0935-1221/2011/0023-2132

[13] Pynn, R. (1979) Incommensurable Structures. Nature, 281, 433-437. http://dx.doi.org/10.1038/281433a0

[14] Tauson, V.L. and Akimov, V.V. (1997) Introduction to the Theory of Forced Equilibria: General Principles, Basic Concepts, and Definitions. Geochimica et Cosmochimica Acta, 61, 4935-4943. http://dx.doi.org/10.1016/S0016-7037(97)00348-7

[15] Hassan, I. and Buseck, P.R. (1989) Cluster Ordering and Antiphase Domain Boundaries in Hauyne. The Canadian Mineralogist, 27, 173-180.

[16] Hassan, I. and Buseck, P.R. (1989) Incommensurate-Modulated Structure of Nosean, a Sodalite-Group Mineral. The American Mineralogist, 74, 394-410.

[17] Dempsey, M.J. and Taylor, D. (1980) Distance Least-Squares Modeling of the Cubic Sodalite Structure and of the Thermal Expansion of $\mathrm{Na}_{8}\left(\mathrm{Al}_{6} \mathrm{Si}_{6} \mathrm{O}_{24}\right) \mathrm{I}_{2}$. Physics and Chemistry of Minerals, 6, 197-208. http://dx.doi.org/10.1007/BF00309856

[18] Hassan, I. and Grundy, H.D. (1984) The Crystal Structures of Sodalite-Group of Minerals. Acta Crystallographica Section B, 40, 6-13. http://dx.doi.org/10.1107/S0108768184001683

[19] Liebau, F. (2003) Ordered Microporous and Mesoporous Materials with Inorganic Hosts: Definitions of Terms, Formula Notation, and Systematic Classification. Microporous and Mesoporous Materials, 58, 15-72.

http://dx.doi.org/10.1016/S1387-1811(02)00546-2 
Scientific Research Publishing (SCIRP) is one of the largest Open Access journal publishers. It is currently publishing more than 200 open access, online, peer-reviewed journals covering a wide range of academic disciplines. SCIRP serves the worldwide academic communities and contributes to the progress and application of science with its publication.

Other selected journals from SCIRP are listed as below. Submit your manuscript to us via either submit@scirp.org or Online Submission Portal.
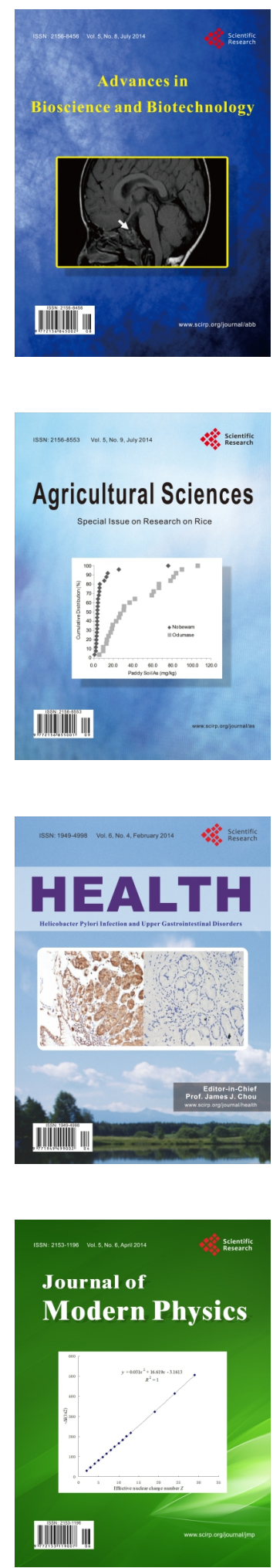
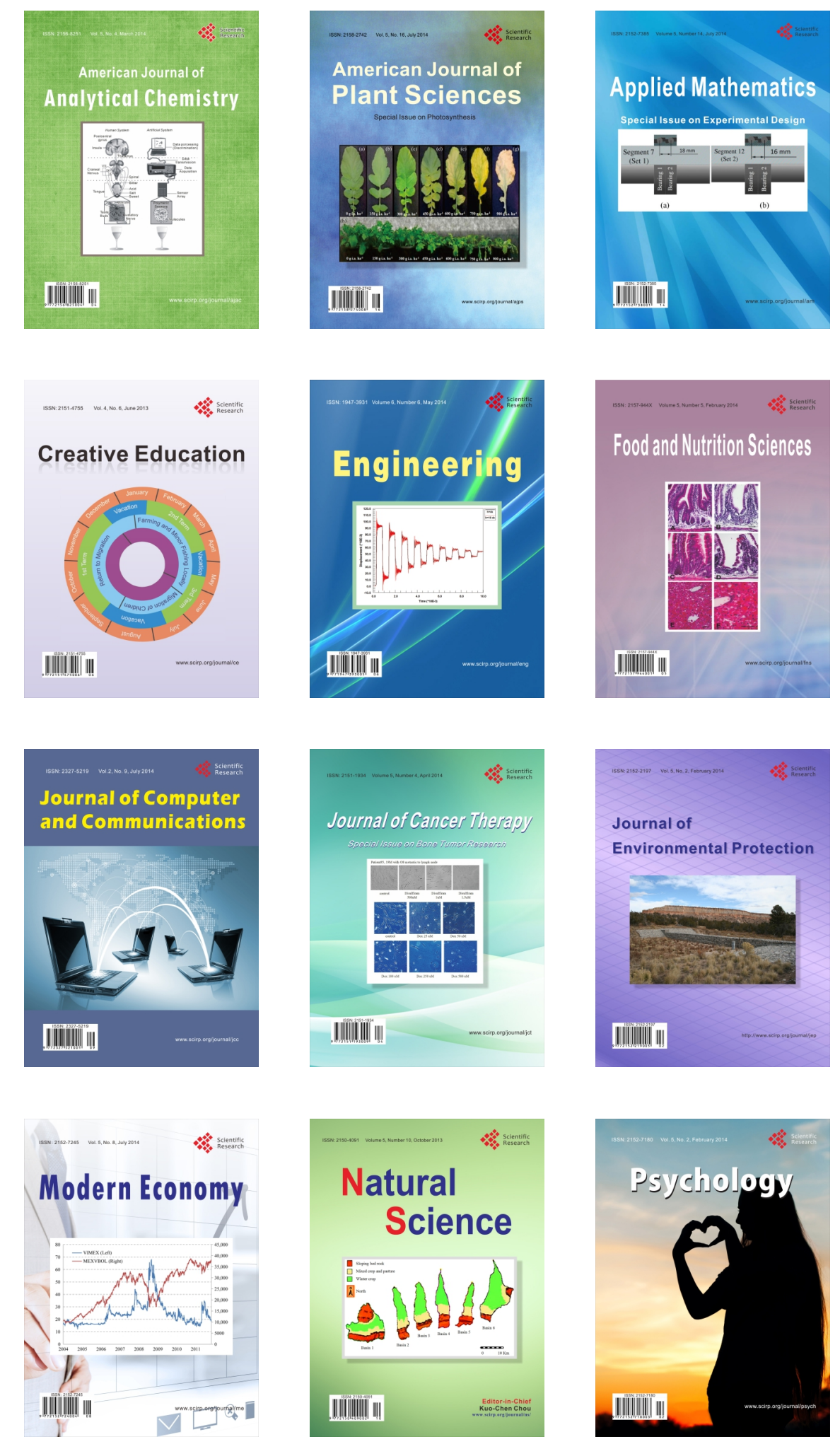